\title{
Tinospora Sinensis (Lour.) Merr. Stem Modulate The TNF-Alpha Expression In HCT- 116 Tumour Cell, Besides the Inhibitory Effect on Cervical, Colon and Breast Cancer Cell Lines and Mycobacterium Tuberculosis H37Rv
}

\author{
Sreelakshmi Bada Venkatappa Gari ${ }^{1, *}$, Ramalingam Peraman ${ }^{2}$
}

Sreelakshmi Bada Venkatappa Gari $^{1, *}$, Ramalingam Peraman ${ }^{2}$

'Research Scholar, Faculty of Pharmaceutical Sciences, Jawaharlal Nehru Technological University Anantapur (JNTUA), Anantapur, Andhra Pradesh 515002, INDIA.

2 Professor of Pharmaceutical and Medicinal chemistry RERDS-Centre for Pharmaceutical Research, Raghavendra Institute of Pharmaceutical Education and Research (RIPER)-Autonomous, Anantapur, Andhra Pradesh 515721, INDIA.

\section{Correspondence}

Sreelakshmi Bada Venkatappa Gari

Research Scholar, Faculty of

Pharmaceutical Sciences, Jawaharlal Nehru Technological University Anantapur (JNTUA), Anantapur, Andhra Pradesh

515002, INDIA

Phone no: +91-9392637310

E-mail: Srilakshmi.bada@gmail.com

History

- Submission Date: 21-08-2020;

- Review completed: 09-10-2020.

- Accepted Date: 12-10-2020.

DOI : 10.5530/pj.2021.13.2

Article Available online

http://www.phcogj.com/v13/i1

\section{Copyright}

(C) 2021 Phcogj.Com. This is an open access article distributed under the terms of the Creative Commons Attribution 4.0 International license.

\begin{abstract}
Background: The present study was designed to evaluate TNF-Alpha experession, anticancer and antitubercular properties for the stem extracts of Tinospora sinensis (TS). Objective: natural product research is widely used for identifying hit molecules for life threatening diseases including cancer, tuberculosis and drug resistant infections. Materials and Methods: There were three polarity dependant solvent extracts obtained through cold maceration process using ethanol (ELTS), ethyl acetate (EATS) and n-hexane (NHTS), respectively. The extracts were subjected to MTT assay for their anticancer potential against HeLa (cervical cancer), MCF-7 (breast cancer) and HCT116 (colon cancer) cell lines, and based on the results, NHTS was subjected to flow cytometry for TNF-Alpha expression in HCT-116 cells. The antitubercular activity for the extracts was performed against Mycobacterium tuberculosis $\mathrm{H}_{37} R v$ (Mtb) by luciferase reporter phage (LPS) assay method. Results: The result of anticancer screening revealed that $n$-hexane extracts showed the significant inhibition $(p<0.05)$ on HCT-116 cells with the $\mathrm{IC}_{50}$ of $177.4 \mu \mathrm{g} / \mathrm{ml}$, whereas EATS and ELTS were equally active on HeLa with the respective $\mathrm{IC}_{50}$ of 236 and $277 \mu \mathrm{g} / \mathrm{ml}$. The NHTS was significantly effective on decreasing $(\mathrm{P}<0.05)$ TNF-Alpha expression (31.27 MFU) in HCT-116 cells and is closely active with standard simvastatin (26.7 MFU) against the control (7.06 MFU). The antitubercular activity results revealed the equi-potency of both NHTS and EATS on Mtb with growth inhibition of $84 \%$ at $100 \mu \mathrm{g} / \mathrm{ml}$. The GC-MS analyses of NHTS confirmed the presence of Berberine, palmatine, tembertarine, magniflorine, choline and tinosporin. Conclusion: Overall, we scientifically support the traditional use Tinospora sinensis stem in the treatment of cancer and immune diseases.
\end{abstract}

Key Words: Tinospora sinensis, Anticancer, Antitubercular, Immunomodulatory, TNF-Alpha, HCT-116.

\section{INTRODUCTION}

Since ancient time, many countries have been practicing traditional medicines for several life threatening diseases ${ }^{1}$. In recent time, there has been remarked drug development researches based on traditional knowledge and thus, many useful explorations were conducted by scientists for identification of diverse group of medicinal plants ${ }^{2}$. Today, the co-administration of immunomodulatory agents or the use of immunoboosters are in clinical practice for treating autoimmune disorders, tubercular infections, inflammatory conditions and cancer ${ }^{3}$. Among them, cancer and multi-drug resistant tuberculosis (MDR-TB) are continuously evolving as major health burden prevailing globally ${ }^{4}$. The interleukins (IL-1, IL-10, IL-12) and tumor necrosis factor (TNF) can significantly modulate macrophage the activity, thus they can interfere in tumour growth. In human, TNF is a pleiotropic cytokine exhibit significant role in immune homeostasis, inflammatory effect and host defense. In tumour, TNF can induce apoptosis, necrosis, angiogenesis, immune cell activation, differentiation, and cell migration. TNF in combination with melphalan has already been used in treating soft tissue sarcoma and also few preclinical data suggested that TNF neutralization can fight cancer-associated complications ${ }^{5}$. Due the drug resistance of Mycobacterium tuberculosis and the reduced the immune response of host, now the disease is prevailing as multi-drug resistant (MDR), extensively resistant (XDR) and totally resistant tuberculosis (TDR-TB) ${ }^{6}$.

Tinospora sinensis (Family: Menispermaceae; Syn: Tinospora cordifolia) has been documented as "Amrita" or "Guduchi" in folklore and Indian Systems of Medicine (ISM). In ISM, the plant was traditionally used in the treatment of cancer, diabetes, dyspepsia, fevers, urinary problems, skin diseases, jaundice, diarrhoea and dysentery ${ }^{7}$. The whole plant extract has been tested for anticancer activity on HeLa cells, but at a very high concentration of 100 $\mathrm{g} / \mathrm{ml}^{8}$. In view of immunomodulatory effect of TS, demonstrated immunosuppression on obstructive 
jaundice patients ${ }^{9}$.Reports on antileishmanial activity and anti mycobcterial activity for TS are available ${ }^{10}$. There is evidence that G1$4 \mathrm{~A}$, a polysaccharide derived from TS inhibits Mtb survival ${ }^{11,12}$.

\section{MATERIAL AND METHODS}

\section{Chemicals, reagents and cell lines}

Anticancer screening: Human cervical cancer cell line (HeLa), Human colorectal cancer cell line (HCT-116), Human breast cancer cell line (MCF-7) were sourced from National Centre for Cell Science (NCCS), Pune, India. Cell culture medium used was Dulbecco's modified Eagle Medium (AL111), fetal bovine serum (RM10432), MTT Reagent $(5 \mathrm{mg} / \mathrm{ml}$ ) and Dulbecco's phosphate-buffered saline (DPBS) (TL1006) were obtained from Himedia, India. Camptothecin (C9911), dimethyl sulphoxide were procured from Sigma Alrich, India. Immunomodulatory effect: Lipopolysacchride (LPS25) and simvastatin were obtained from Sigma Alrich, India). The PE Rat AntiMouse TNF-Alpha antibody was procured from Biosciences Ltd, India. Antitubercular screening: Cell suspension equivalent to \#2 MacFarland units was prepared by inoculating the log phase culture of $M$. tuberculosis from LJ slope into G7H9, DMSO (1\%), mycobacteriophage phAETRC202, $0.1 \mathrm{M} \mathrm{CaCl} 2,100 \mu \mathrm{l}$ of D-Luciferin. All other reagents and solvents used in the extraction procedures were Analytical Reagent Grade procured from Merck, Mumbai, India.

\section{Collection and authentication of plant part}

Fresh stem of Tinospora sinensis (TS) were collected from the Anantapuramu, Andhra Pradesh, India. A voucher specimen of the plant part and plant was deposited at the Biodiversity conservation division, Sri Krishnadevaraya University, Anantapuramu, AP, India (Voucher No. 55585). The collected plant material was washed with distilled water for removal of mud, dust and contaminants, and then shade dried at room temperature for 10 days. The dried stem material was blended into fine powdered. The powdered was stored in air tight container until further use.

\section{Preparation of extracts}

About $100 \mathrm{~g}$ of TS stem powder was extracted by cold maceration technique using ethanol (95\%), ethyl acetate and n-hexane. Here, TS stem powder was soaked into each solvent and was kept 7 days at room temperature $\left(25 \pm 2{ }^{\circ} \mathrm{C}\right)$ in dark room. On $7^{\text {th }}$ day, each extract was filtered using Whatman No.1 filter paper and the obtained filtrate was concentrated using rotary evaporator. All these extracts, namely ethanolic extract (ELTS), ethyl acetate extract (EATS), n-hexane (NHTS) were concentrated into semisolid mass and stored in air tight container until further use ${ }^{13}$.

\section{Phytochemical analysis of extracts}

$100 \mathrm{mg}$ of each, stem extract of TS was dissolved in $100 \mathrm{ml}$ of respective mother solvent to get the concentration of $1 \mathrm{mg} / \mathrm{ml}$. The diluted extract solution was filtered and subjected for various qualitative phytochemical tests as per the reported procedure. The chemical tests performed were Dragendorff's and Mayer's test (alkaloids), Shinoda test, ferric chloride test and lead acetate test (flavonoids), Molisch's test (carbohydrates), Biuret test (protein), Salkowski test (steroids/ terpenoids), Borntrager'stest (andhraquinone glycosides), Sodium Picrate test (cyanogenic glycoside), alcohol extract test (coumarin glycosides), Foam test (saponins) and ferric chloride test, Iodine test, nitric acid test (tannin and phenols) ${ }^{14}$.

\section{Thin Layer Chromatography of extracts}

The TS stem extracts were spotted on silica gel $\mathrm{GF}_{254}$ pre-coated TLC plates. The spotted TLC Plates were developed using a pre-optimized mobile phase consisted of n-hexane and ethyl acetate $(70: 30 \% \mathrm{v} / \mathrm{v})$ in the saturated TLC trough chambers. After optimum development, plates were removed and air dried for 10-15 minutes. The plates detected by visual examination, UV light and iodine chamber. The appearance of colour of the spots under iodine vapour and UV light has also been considered for identification of chemical constituents. The retardation factor $\left(\mathrm{R}_{\mathrm{f}}\right)$ values for the major spots were calculated and reported ${ }^{15}$.

\section{Cell viability Assay for anticancer activity}

The MTT assay was employed to determine the inhibitory effect of TS stem extracts on tumour cell proliferation. In this procedure, seed $200 \mu \mathrm{l}$ cell suspension of each (HeLa, HCT-116), MCF-7) in a 96-well plate at required cell density $(20,000$ cells per well) were allowed to grow for 24 hours. Then TS stem extracts (NHTS, EATS, ELTS) were added and the plates were incubated for $48 \mathrm{hrs}$ at $37^{\circ} \mathrm{C}$ in a $5 \% \mathrm{CO}_{2}$ atmosphere. At the end of incubation period, plates were removed and added yellow coloured MTT reagent (3-(4,5-dimethylthiazol-2-yl)-2,5diphenyl tetrazolium bromide) to a final concentration of $0.5 \mathrm{mg} / \mathrm{mL}$ of total volume. The plate was wrapped with aluminium foil to avoid light exposure and further incubated for 3 hours (Note: The incubation time varied for different cell lines). Then $100 \mu \mathrm{l}$ of solubilisation solution (DMSO) was added with gentle stirring in a gyratory shaker to enhance dissolution blue MTT formazan crystals. The absorbance was observed on ELISA reader at $570 \mathrm{~nm}$ and $630 \mathrm{~nm}$. The $\mathrm{IC}_{50}$ value was determined by using linear regression equation i.e. $\mathrm{Y}=\mathrm{mx} \pm \mathrm{c}$. Here, $\mathrm{Y}=50, \mathrm{~m}$ and c values were derived from the viability graph ${ }^{16}$.

\section{Assessment of cell morphology: Acridine orange - Ethidium bromide staining}

Acridine orange is a vital dye and will stain both live and dead cells. Acridine orange is a cell permeable nucleic acid selective dye that emits green fluorescence when bound to dsDNA. HCT-116 cells were seeded in 24 well plate at a density of $5 \times 10^{4} \mathrm{cell} /$ well and incubated for $24 \mathrm{~h}$, then treated with test $\mathrm{dug}^{17}$. After $24 \mathrm{~h}$ the acridine orangeethidium bromide working solution is prepared and followed the staining procedure to differentiate the live, apoptotic and necrotic cells in treated and untreated cells by using fluorescence microscope with excitation $(488 \mathrm{~nm})$ and emission $(550 \mathrm{~nm})$ at $200 \mathrm{X}$ magnification.

\section{Luciferase Reporter Phage (LRP) assay for Antitubercular activity}

Antitubercular activity for the extracts was studied on $M$. tuberculosis $H_{37} R v(\mathrm{Mtb})$ using luciferase reporter phage (LRP) assay method. In each cryo vials, $10 \%$ albumin dextrose and $0.5 \%$ glycerol supplemented $350 \mu \mathrm{l}$ of G7H9 broth was taken and added aliquots of each TS stem extracts (NHTS, EATS, ELTS) to get the final concentration of 100 and $500 \mu \mathrm{g} / \mathrm{ml}$. One hundred microlitres of Mtb cell suspension was added to all the vials and incubated at $37^{\circ} \mathrm{C}$ for 72 hours using DMSO (1\%) as solvent control. After first incubation, $50 \mu$ l of high mycobacteriophage phAETRC202 and $40 \mu \mathrm{l}$ of $0.1 \mathrm{M} \mathrm{CaCl}_{2}$ solution was added into the test and control vials. Then the second incubated was carried out at $37^{\circ} \mathrm{C}$ for 4 hours. At the end of second incubation, $100 \mu$ from each vial was transferred to luminometer cuvette and then added $100 \mu$ of D-luciferin and then relative light unit (RLU) was measured using luminometer. The test extract showing RLU reduction by $50 \%$ or more when compared to control was considered as active extract ${ }^{18}$.

\section{Flow cytometry assay for TNF-Alpha expression}

Based on results of anticancer screening, NHTS was chosen for flow cytometry assay. In this, HCT-116 cells in a 6-well plate at a density of 3 $\mathrm{x} 10^{5}$ cells $/ 2 \mathrm{ml}$ were incubated in a $\mathrm{CO}_{2}$ incubator overnight at $37^{\circ} \mathrm{C}$ for 12 hours. Prior to NHTS treatment, except the untreated cell culture, all treatment cell cultures were stimulated with lipopolysaccharide (LPS) 
at $2 \mu \mathrm{g} / \mathrm{ml}$ concentration for $12 \mathrm{~h}$. Cells treated with LPS were used as a negative control for anti-inflammatory marker expression whilst the cells with culture media was used as normal control. The cells treated with LPS and simvastatin was used as a positive control. Test cultures were treated with required test concentration of the NHTS and incubated for $24 \mathrm{~h}$. At the end of $24 \mathrm{~h}$, the medium was removed from all wells and washed with PBS, added $200 \mu \mathrm{l}$ of trypsin-EDTA solution and then incubated at $37^{\circ} \mathrm{C}$ for 4 minutes. Further, $2 \mathrm{ml}$ of culture medium was added and then cells were harvested directly into $12 \mathrm{x}$ $75 \mathrm{~mm}$ polystyrene tubes. The tubes were centrifuged for five minutes at $2000 \mathrm{rpm}$ at $25^{\circ} \mathrm{C}$ and then carefully decanted the supernatant. The cells were washed with PBS and added $0.5 \mathrm{~mL}$ of BD Cytofix/Cytoperm solution and waited for 10 minutes. Then, washed with $0.5 \%$ bovine serum albumin (BSA) in $1 \mathrm{X}$ phosphate-buffered saline (PBS) and $0.1 \%$ sodium azide and added $20 \mu \mathrm{L}$ of FITC-Mouse Anti Human TNF Alpha antibody, mixed thoroughly and incubated for 30 minutes in the dark at room temperature $\left(20^{\circ}\right.$ to $\left.25^{\circ} \mathrm{C}\right)$. After incubation, washed with $1 \mathrm{X}$ PBS with $0.1 \%$ sodium azide, added $0.5 \mathrm{~mL}$ of PBS, mixed thoroughly, and analyze ${ }^{19}$.

\section{Gas Chromatography-Mass Spectroscopy (GC-MS)}

The NHTS was subjected to GC-MS analysis on the instrument GCMS SHIMADZU GC-2010 with using short $(<5 \mathrm{~m})$ sin column or two column with maintains a constant mass flow rate of carrier gas (helium). Initially oven temperature was maintained at $70^{\circ} \mathrm{C}$ for 2.0 minutes, and the temperature was gradually increased up to $300^{\circ} \mathrm{C}$ at $10.0 / 35.0$ minutes and $4.0 \mu \mathrm{l}$ of sample was injected for analysis. The flow rate of helium gas was set to $1.5 \mathrm{ml} / \mathrm{min}$. The sample injector temperature was maintained at $260^{\circ} \mathrm{C}$ and the split ratio was 20 throughout the experiment periods. The ionization mass spectroscopic analysis was done with $70 \mathrm{eV}$. The mass spectra were recorded for the mass range 40$1000 \mathrm{~m} / z$ for about 35 minutes. Identification of compounds separated was based on their mass spectra, detected by using electronic signals ${ }^{20}$.

\section{Statistical analysis}

The results of all series of experiments were performed in triplicates and expressed as mean \pm SD (standard deviation). Cell quest software version 6.0, Graph pad Prism 8.01 was used for quantitative analysis and graphical data. The results obtained were expressed as the mean \pm standard deviation. Significance was calculated using one-way ANOVA and student ' $\mathrm{t}$ ' test. $\mathrm{P}<0.05$ indicated a significant difference.

\section{RESULTS}

\section{Phytochemical analysis of extracts}

These crude extracts were resinous in nature and their \% yields were 6.2, 8.9 and $8.4 \%$ respectively for $n$-hexane, ethyl acetate and ethanol. Thus the obtained extracts were tested for phytochemical tests and revealed presence of three common chemical constituents including alkaloids, glycosides and saponins (Table 1).

\section{Thin Layer Chromatography of extracts}

The developed TLC plate was illuminated under UV light which showed different colour spots with different $R_{f}$ values. The spot colour observes under UV light (Table 1).

\section{Cell viability Assay for anticancer activity}

NHTS and EATS are relatively more active against HCT-116 ( $\mathrm{IC}_{50}: 177$ $\mu \mathrm{g} / \mathrm{ml})$ and HeLa $\left(\mathrm{IC}_{50}: 236 \mu \mathrm{g} / \mathrm{ml}\right.$ ), respectively (Figure 2). However, ELTS was closely active on HeLa with $\mathrm{IC}_{50}$ value of $277 \mu \mathrm{g} / \mathrm{ml}$ as EATS (Table 2). The $\mathrm{IC}_{50}$ value for each extract was obtained from percentage of cell viability (Figure 1).

\section{Assessment of cell morphology: Acridine orange - Ethidium bromide staining}

The effect of test dug in HCT-116 cell line upon $24 \mathrm{~h}$ incubation showing morphological changes like membrane blebbing, condensed nuclei and apoptotic body formation in concentration dependent manner (Figure $3)$.

\section{Luciferase Reporter Phage (LRP) assay for Antitubercular activity}

The antitubercular activity of stem extracts of TS was performed on Mycobacterium tuberculosis $H_{3} R v$ by LRP assay (Table 2). Each extract was screened at 100 and $500 \mu \mathrm{g} / \mathrm{ml}$. At $100 \mu \mathrm{g} / \mathrm{ml}$, both NHTS and EATS has shown \% inhibition activity of $84 \%$ whereas ELTS shown $62 \%$ (Figure 4 ).

Table 1: Results of phytochemical screening of $T$. sinensis stem extracts.

\begin{tabular}{|c|c|c|c|c|}
\hline S. No. & Parameters & NHTS & EATS & ELTS \\
\hline 1. & Extraction process & Maceration & Maceration & Maceration \\
\hline 2. & Extract Color & Brownish green & Brown & Light brown \\
\hline 3. & Extract Texture & Solid & Semi-solid & Semi-solid \\
\hline 4. & $\%$ Yield & $6.2 \%$ & $8.9 \%$ & $8.4 \%$ \\
\hline \multirow[t]{10}{*}{5.} & \multicolumn{4}{|c|}{ Qualitative test } \\
\hline & Alkaloids & + & + & + \\
\hline & Steroids & + & + & - \\
\hline & Glycosides & + & + & + \\
\hline & Amino acids & + & - & + \\
\hline & Carbohydrates & - & + & + \\
\hline & Flavonoids & - & - & - \\
\hline & Tannins & - & - & - \\
\hline & Saponins & + & + & + \\
\hline & Diterpenes & - & + & + \\
\hline \multirow[t]{6}{*}{6.} & \multicolumn{4}{|c|}{ TLC profile } \\
\hline & Major spots & 4 & 4 & 3 \\
\hline & Retardation factor & 0.32 (Light yellow) & 0.42 (Light yellow) & 0.56 (light brown) \\
\hline & & 0.48(Light brown) & 0.49 (Yellow green) & 0.72 (yellow) \\
\hline & & 0.76 (Light blue) & 0.69 (Light blue) & 0.98 (Light green) \\
\hline & & 0.79 (Yellow) & 0.98 (green) & \\
\hline
\end{tabular}

(+) Present, (-) Absent 
Table 2: Biological Screening results of $T$. sinensis stem extracts.

\begin{tabular}{|c|c|c|c|c|c|c|}
\hline \multirow[t]{2}{*}{ S. NO } & \multirow[t]{2}{*}{ Extracts } & \multicolumn{3}{|c|}{$\begin{array}{l}\text { Anticancer activity } \\
\text { by MTT Assay }\left(\mathrm{IC}_{50} \text { value in } \mu \mathrm{g} / \mathrm{ml}\right)\end{array}$} & \multicolumn{2}{|c|}{$\begin{array}{l}\text { Antitubercular activity by } \\
\text { LPS Assay \% Inhibition on M. tuberculosis }\end{array}$} \\
\hline & & HeLa & НСТ-116 & MCF-7 & $100 \mu \mathrm{g} / \mathrm{ml}$ & $500 \mu \mathrm{g} / \mathrm{ml}$ \\
\hline 1 & NHTS & $465.75 \pm 15.41$ & $177.4 \pm 14.9$ & $425.5 \pm 16.2$ & $84.00 \pm 1.00$ & $87.50 \pm 1.50$ \\
\hline 2 & EATS & $236 . \pm 12.18$ & $365.35 \pm 12.26$ & $400.5 \pm 15.4$ & $84.50 \pm 0.50$ & $94.00 \pm 2.00$ \\
\hline 3 & ELTS & $277.3 \pm 8.10$ & $395.0 \pm 11.17$ & $563.2 \pm 18.05$ & $62.50 \pm 0.50$ & $74.50 \pm 0.50$ \\
\hline
\end{tabular}
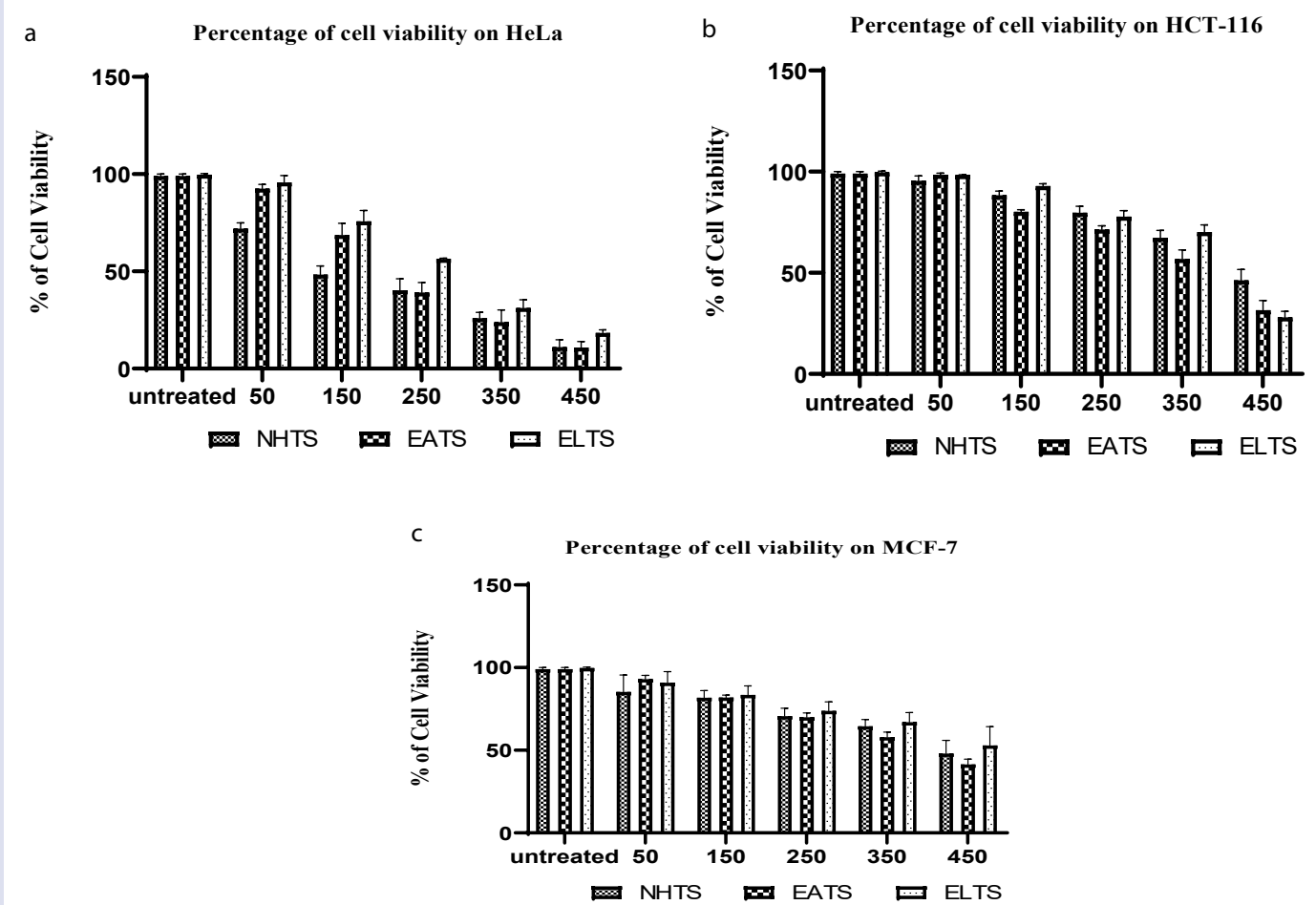

Figure 1: Effect of T. sinensis stem extracts against anticancer activity in MTT assay on HeLa (a), HCT-116 (b) and MCF-7 (c) cell lines. Data is represent as mean and. standard deviation $(n=3)$. Statistical significance was assessed using one way ANOVA $\left({ }^{*} p<0.05\right)$ as compared to untreated.

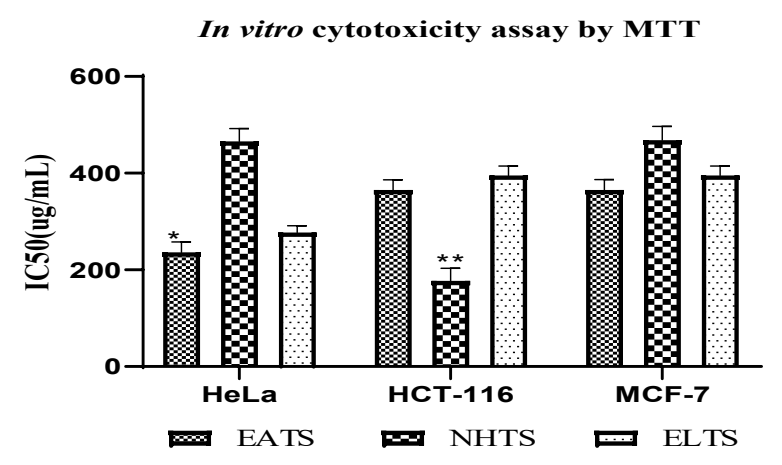

Figure 2: Cytotoxicity of $T$. sinensis stem extracts on HeLa, HCT-116 and MCF-7 cell lines. Data is represented as mean and standard deviation $(n=3)$. Statistical significance was assessed using one way ANOVA $\left({ }^{* * *} p<0.01\right)$ as compared to each group. 


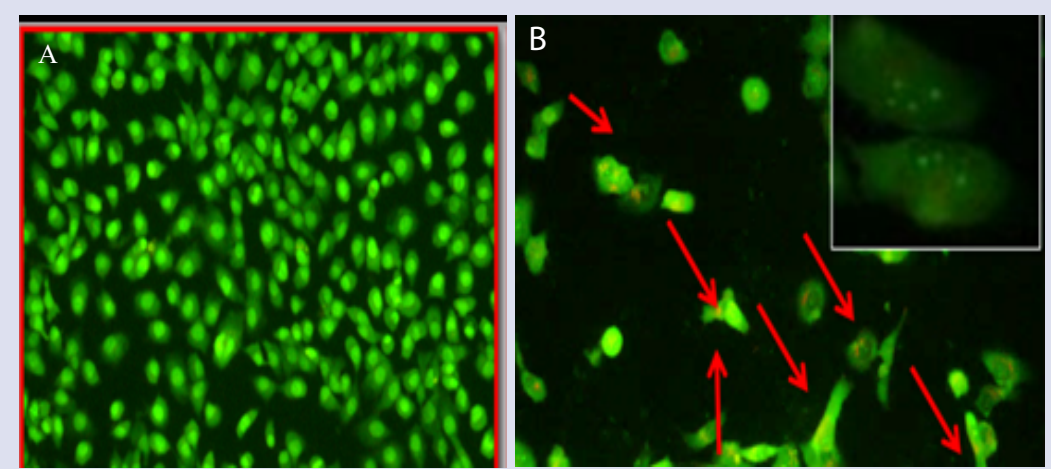

Figure 3: Stains the acridine orange/ethidium bromide staining in control $(A)$ and -treated (B) T. sinensis HCT-116 cells. Arrow marks indicate the DNA damage as evidenced by nuclear staining with ethidium bromide.

In vitro antitubercular activity by LRP assay

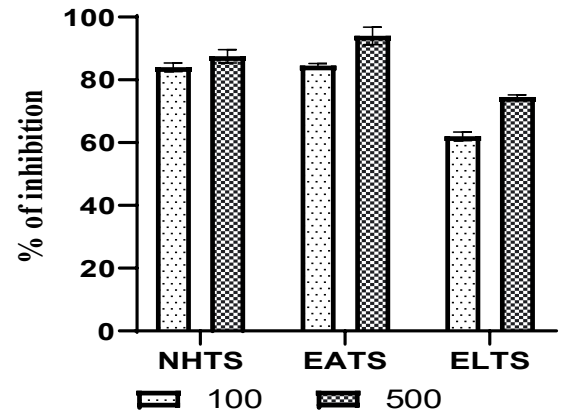

Figure 4: In vitro antitubercular activity of $T$. sinensis stem extracts on LRP assay. Data is represented as mean and standard deviation $(n=3)$. Statistical significance was assessed using one way ANOVA $\left({ }^{* * *} p<0.001\right)$ as compared to each group.

\section{Flow cytometry assay for TNF-Alpha expression}

The NHTS test extact showed 31.27 of mean fluorescence intensity for TNF-Alpha expression whereas standard drug simvastatin showed 26.7 mean fluorescence intensity against the control value of 7.06 (Table 3). The concentrations used were $2 \mu \mathrm{g} / \mathrm{ml}, 25 \mu \mathrm{g} / \mathrm{ml}$ and $107.2 \mu \mathrm{g} / \mathrm{ml}$ respectively for LPS (lipopolysachride), standard simvastatin and test extract. Histogram of the gated HCT-116 singlet distinguishes cells at the M1 and M2 phases, Here M1 refers to negative expression region and $\mathrm{M} 2$ refers to the positive expression region (Figure 5).

\section{Gas Chromatography-Mass Spectroscopy (GC-MS)}

The n-hexane extracts revealed that the presence of phytochemicals such tembetarine $(\mathrm{m} / \mathrm{z} 344.4)$, berberine $(\mathrm{m} / \mathrm{z} 336.4)$, magnoflorine $(\mathrm{m} / \mathrm{z} 342.41)$, palmatine $(\mathrm{m} / z$ 352.4), choline $(\mathrm{m} / \mathrm{z} 104.7)$ and Tinospoin $(\mathrm{m} / z$ 358.39) The postulated chemical Structure (Figure 7) are presented and the Chromatogram (Figure 6).

\section{DISCUSSION}

Considering the traditional knowledge of the plant, Tinospora sinensis (TS), this work was designed to evaluate the stem part of the plant for its immunomodulatory effect in tumour cell in addition to anticancer screening on cervical, colon and breast tumour cell lines. The stem part prepared as extracts by cold maceration with n-hexane (NHTS), ethyl acetate (EATS) and ethanol ELTS). Thus the obtained extracts were tested for phytochemical tests and revealed presence of three common chemical constituents including alkaloids, glycosides and saponins in all extracts. Steroids are absent in ELTS whilst diterpenes and carbohydrates are absent in NHTS. Previous experiments on Tinospora sinensis stem extracted with methanol shown the presence of alkaloids, glycosides, saponins, steroids and flavanoidds ${ }^{21}$. Each extract of TS stem was tested on HeLa (cervical cancer), MCF - 7 (breast cancer) and HCT- 116 (colon cancer) cell lines with respective serial concentrations of $50 \mu \mathrm{g} / \mathrm{ml}, 150 \mu \mathrm{g} / \mathrm{ml}, 250 \mu \mathrm{g} / \mathrm{ml}, 350 \mu \mathrm{g} / \mathrm{ml}$ and $450 \mu \mathrm{g} / \mathrm{ml}$ in triplicate. There was proportional relationship found between $\%$ cell killed and concentration of extracts. However, the comparative \% cell kill among these extract showed diversity in the cytotoxicity potential with respect to type of cell line. The n-hexane extract (NHTS) is more potent on HCT-116 cell and demonstrated 2-3 fold potent as compared to other test extracts. EATS and ELTS are less and equally active on HeLa cells but not on MCF-7. The whole plant extract has been tested for anticancer activity on HeLa cells, but at a very high concentration of $100 \mathrm{~g} / \mathrm{ml}$. Hence this report neither reliable to state the anticancer potency of the specific plant like leaves, stem etc., nor to reject the plant for anticancer activity ${ }^{22}$. The decreased expression of TNFAlpha is leading to antitumor property of any test drug. The chronic inflammation has long been associated with the development of cancer. In connection with the available evidence on the immunomodulatory effect of TS on IL-1 and IL-12 expression and the obtained cytotoxicity data of TS stem extracts ${ }^{23}$. NHTS and standard simvastatin compounds showed positive expression region, whereas untreated and negative control showed negative expression region. This indicated that the TS 

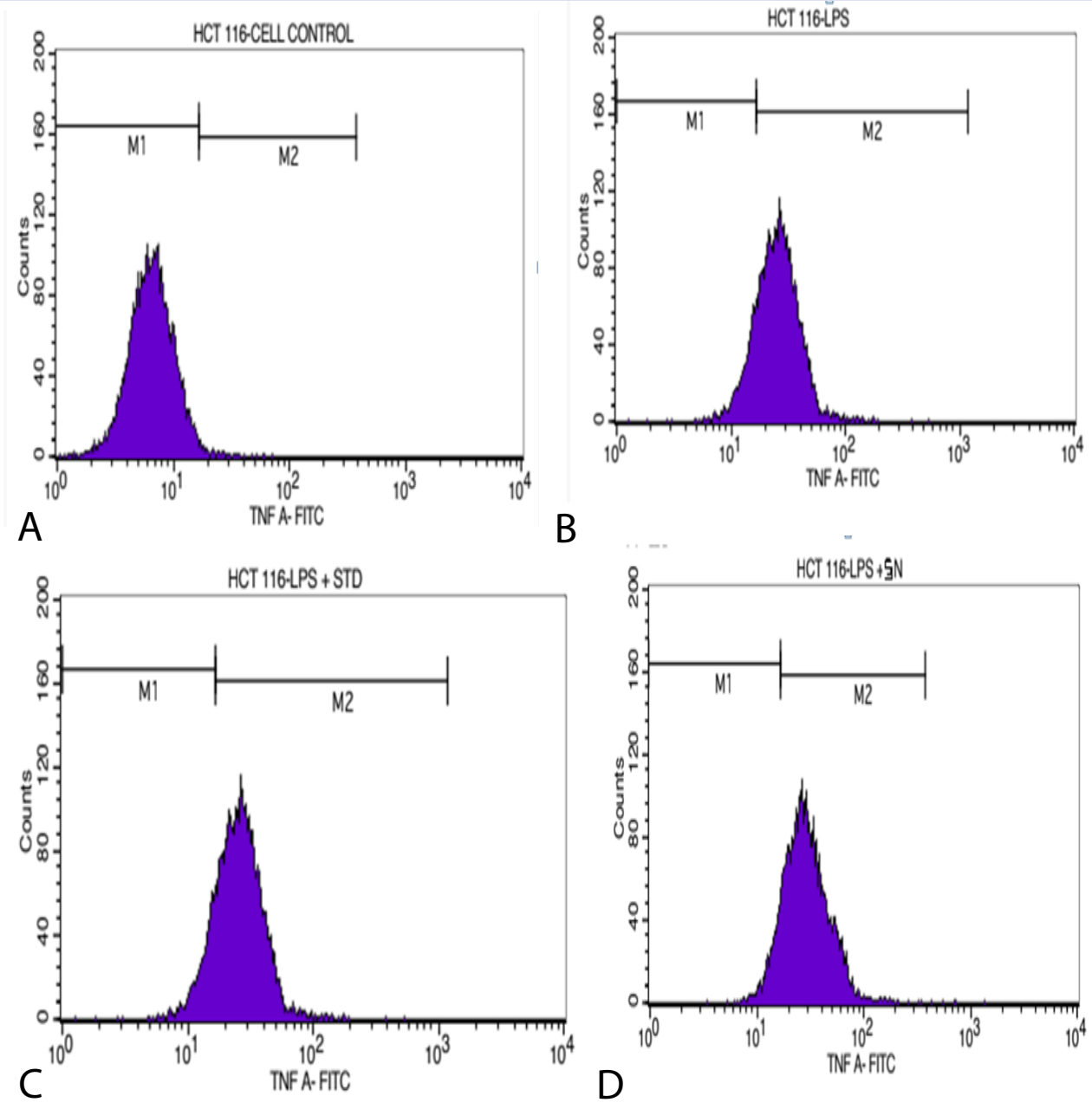

B
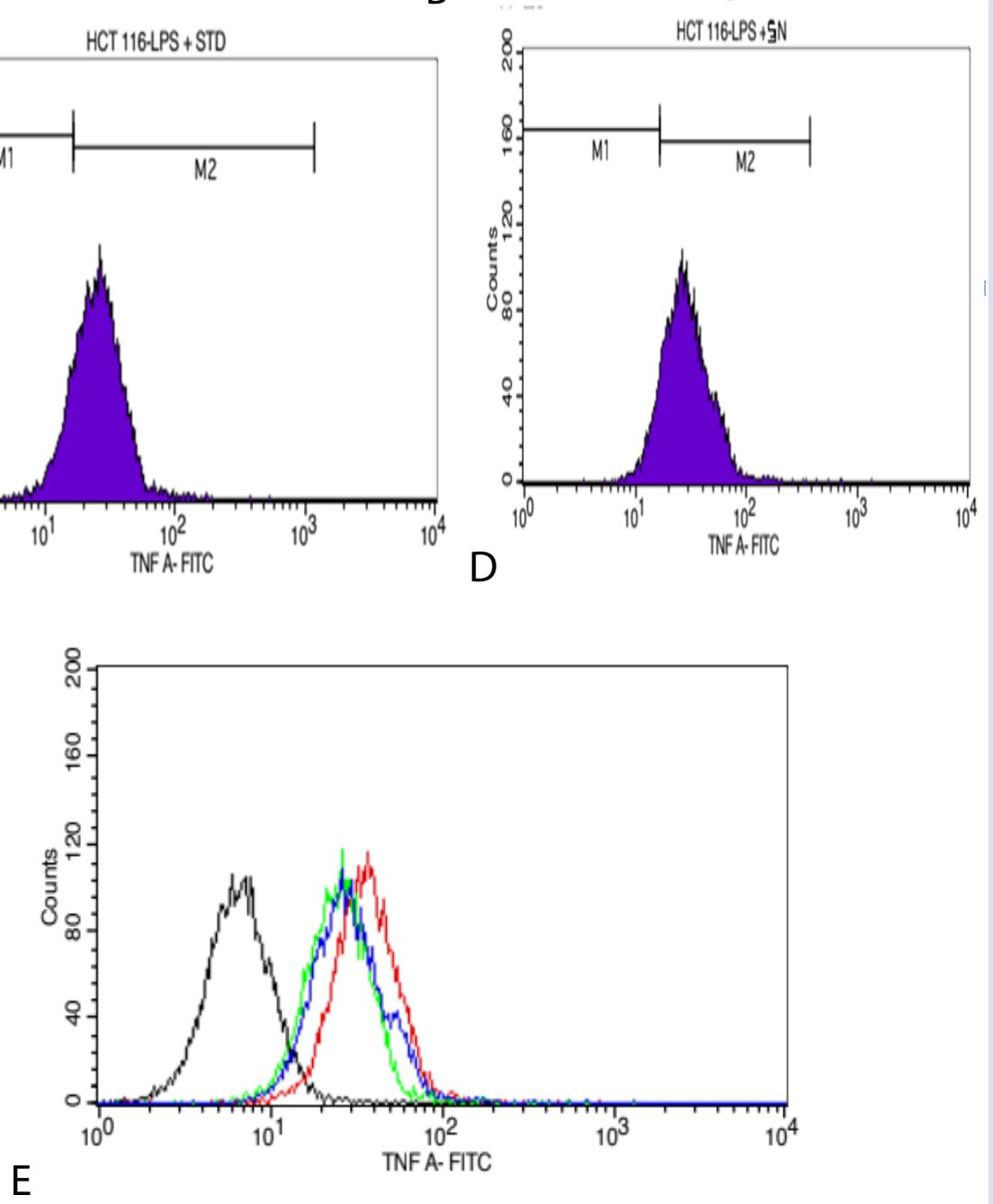

Figure 5: Effect of NHTS extract on mean fluorescence intensity of contol cells (A) negative control (HCT-116 and LPS) (B) Standard (HCT-116, LPS and standard) (C) test drug (HCT-116, LPS and NHTS) using BD FACScalibur, Cell Quest Pro Software (Version: 6.0). Histogram of the gated HCT 116 singlets distinguishes cells at the M1 and M2 phases. (Here M1 refers to negative expression/region and M2 refers to the positive expression/ region). Gating of $\mathrm{M} 1$ and $\mathrm{M} 2$ phases was refined using software (Cell Quest Software, Version 6.0) analysis. (E) histogram graph of TNF-Alpha expression in HCT-116 tumour cell lines for NHTS (black spectra-Cell Control, Blue-HCT116+LPS, Green-Srandard, Red-NHTS. 


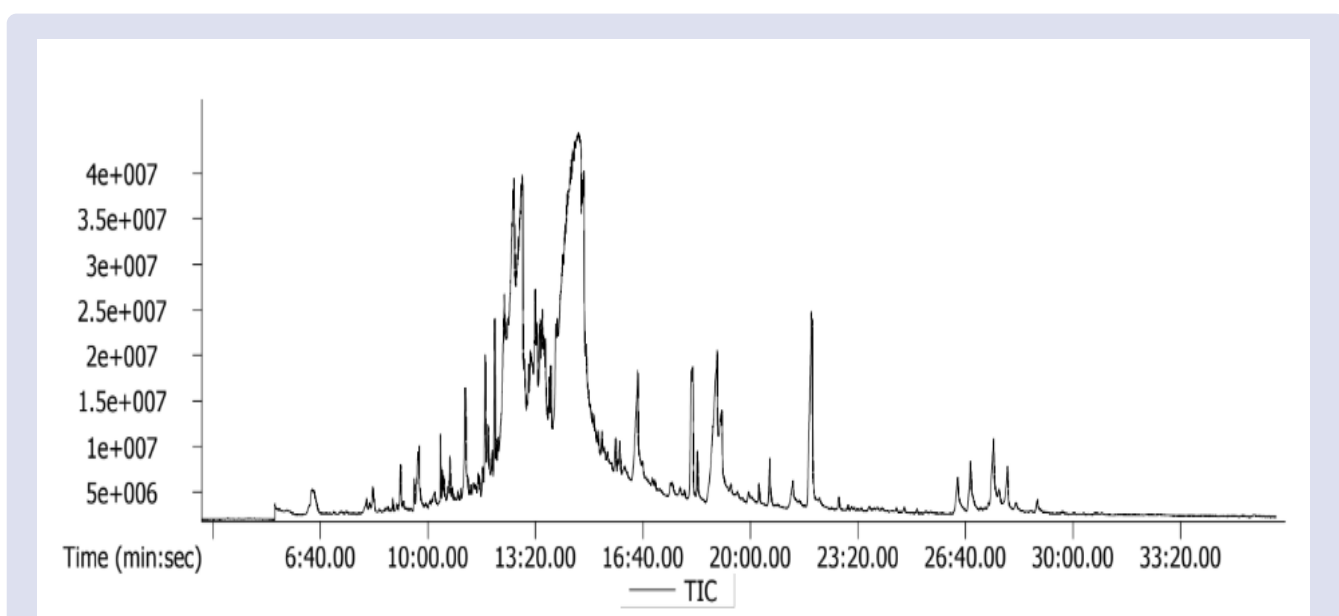

Figure 6: GC-MS chromatogram of $n$-hexane extract of T. sinensis stem (NHTS).

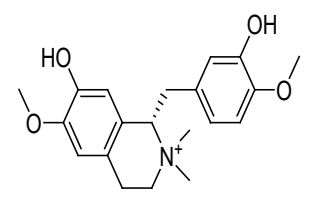

Tembetarine

$\mathrm{m} / \mathrm{z}: 344.4 / 10: 36 \mathrm{~min} / 0.029 \%$<smiles>COc1cc2c(c(O)c1O)-c1c(ccc(OC)c1O)[N+](C)(C)CC2</smiles>

Magnoflorine

$\mathrm{m} / \mathrm{z}: 342.41 / 11: 50 \mathrm{~min} / 0.0113 \%$ $0.0074 \%$

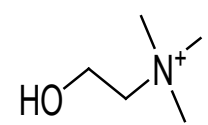

Choline

$\mathrm{m} / \mathrm{z}: 104.7 / 27: 32 \mathrm{~min} / 1.84 \%$

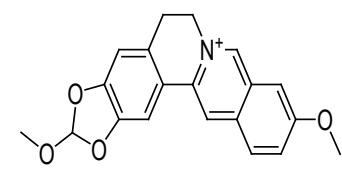

Berberine $m / z: 336.4 / 14: 05$<smiles>COc1ccc2c(c1O)-c1c(cc(O)c(O)c1O)CC[N+]2(C)C</smiles>

Palmatine

$m / z: 352.4 / 13: 25 \mathrm{~min} /$

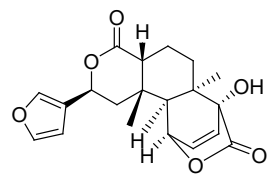

Tinosporin $\mathrm{m} / \mathrm{z}: 358.39 / 14: 41 \mathrm{~min} / 0.0326 \%$

Figure 7: Postulated chemical structure of constituent present in NHTS. 
Gari, et al.: Tinospora Sinensis (Lour.) Merr. Stem Modulate The TNF-Alpha Expression In HCT- 116 Tumour Cell, Besides the Inhibitory Effect on Cervical, Colon and Breast Cancer Cell Lines and Mycobacterium Tuberculosis H37Rv

Table 3: The flow cytometry assay result for TNF-A expression in HCT-116 cells for $n$-hexane.

\begin{tabular}{ccc}
\hline S. NO & Groups & $\begin{array}{c}\text { TNF-Alpha Mean } \\
\text { fluorescence intensity }\end{array}$ \\
\hline 1. & Cell Control & 7.06 \\
2. & Negative Control (LPS) & 38.15 \\
3. & LPS+ Standard (Simvastatin) & 26.7 \\
4. & LPS+NHTS & 31.27 \\
\hline
\end{tabular}

stem decreased the expression of TNF-Alpha expression, and this is due to immunostimulant property. The interleukins (IL-1, IL-10, IL-12) and tumor necrosis factor (TNF) can significantly modulate macrophage the activity, thus they can interfere in tumour growth. In human, TNF is a pleiotropic cytokine exhibit significant role in immune homeostasis, inflammatory effect and host defence. Reported studies showed LRPbased assays are rapidly used to discover the new antitubercular drugs. In LRP assay, drug susceptibility was assessed based on the production of photons by visible mycobacterium infected with specific report phage expressing the firefly luciferase gene. Hence, the antitubercular activity of stem extracts of TS was performed on Mycobacterium tuberculosis $H_{37} R v$ by LRP assay. This report was concurrent with the earlier report but they have screened on dichloromethane extract. However, the relative potency of the TS stem on Mycobacterium tuberculosis is intact ${ }^{24}$. The staining reagent is used for easy determination among live, apoptotic and dead cells after treatment. Acridine orange identifies live cells and ethidium bromide for identification of dead cells. Acridine orange stained live cells appear green and ethidium bromide stained dead cells appear red when visualized by fluorescent microscopy. The GC-MS analyses of NHTS confirmed the presence of Berberine, palmatine, tembertarine, magniflorine, choline and tinosporin.

\section{CONCLUSION}

The n-hexane stem extract of Tinospora sinensis (NHTS) showed the significant cytotoxicity on HCT-116 tumour cells, Antitubercular activity on Mycobacterium tuberculosis $H_{3} R v$ Tinospora sinensis stem can be used for cancer treatment which can boost the immunity in the patient along with its anticancer efficacy.

\section{ACKNOWLEDGMENT}

Authors are thankful to DST-FIST Facility of Raghavendra Institute of Pharmaceutical Education and Research, Anantapur, AP, India for the provided support in phytochemical screening. Authors are thankful to ICMR-National Institute of Research in Tuberculosis (NIRT), Chennai, Tamil Nadu, and India for providing in vitro antitubercular activity data.

\section{FUNDING}

No financial assistance received from funding agency.

\section{REFERENCES}

1. Haidan Yuan, Qianqian Ma, LiYe, Guangchun Piao. The Traditional Medicine and Modern Medicine from Natural Products. Molecules. 2016;21:559-90.

2. Si-Yuan Pan Gerhard L, Si-Hua G, Shu-Feng Z, Zhi-Ling Y, Hou-Qi C, Shuo-Feng $Z$, et al. Historical Perspective of Traditional Indigenous Medical Practices. Current Ren Conserv Herb Res. 2014:5:1-20.

3. Alimuddin Z, Martin R, Ernest D, Markus M. Potential of immunomodulatory agents as adjunct host-directed therapies for multidrug-resistant tuberculosis. MBC Medicine. 2016:14:1-18.

4. Kwonjune J, Seung, Salmaan, Keshavjee, Michae L, Rich1. Multidrug-Resistant Tuberculosis and Extensively Drug-Resistant Tuberculosis. Cold Spring Harb Perspect Med. 2015;5:98-108

5. Wajant $H$. The role of TNF in cancer. Results Probl Cell Differ. 2009;49:1-15.

6. Bhaskor Kolita1, Dhrubajyoti G, Partha Pratim D, Manobjyoti B, Rajib Lochan B. Arabinosyl transferase inhibitor design against Mycobacterium tuberculosis using ligand based drug design approach. Bangladesh J Pharmacol. 2014;9:225-9.
7. Seelakshmi GB, Ramalingam P. In vitro antitubercular, anticancer activities and IL-10 expression in HCT-116 cells of Tinospora sinensis (Lour.) Merr. Leaves extract. Nat Prod Res. 2019;4:1478-6419.

8. Mohamed F, Alajmi, Ramzi A, Mothana, Adnan J, Al-Rehaily, Jamal M, Khaled. Antimycobacterial Activity and Safety Profile Assessment of Alpinia galanga and Tinospora cordifolia. Evid Based Complementary and Altern Med. 2018;27:1-12

9. Rege N, Bapat RD, Koti R, Desai NK, Dahanukar S. Immunotherapy with Tinosporacordifolia: a new lead in the management of obstructive jaundice. Indian J Gastroenterol. 1993:12: 5-8.

10. Maurya R, Gupta P, Chand K, Kumar M, Dixit P, Singh N, Dube A. Constituents of Tinospora sinensis and their antileishmanial activity against Leishmania donovani. Nat Prod Res. 2019;23:1134-43.

11. Adhvaryu MR, Reddy N, Parabia MH. Effects of four Indian medicinal herbs on Isoniazid-, Rifampicin-and Pyrazinamide- induced hepatic injury and immunosuppression in guinea pigs. World J of Gastroenterol. 2007:13:3199 205

12. Gupta PK, Chakraborty P, Kumar S, Singh PK, Rajan GR, Sainis KB. G1-4A, a polysaccharide from Tinospora cordifolia inhibits the survival of Mycobacterium tuberculosis by modulating host immune responses in TLR4 dependent manner. 2016. PLoS One: 11:54-72.

13. Bala $M$, Pratap $K$, Verma $P k$, Singh $B$, Padwad $Y$, Validation of ethno medicina potential of Tinospora cordifolia for anticancer and immunomodulatory activities and quantification of bioactive molecules by HPTLC. J Ethnopharmacol 2015;4:131-7.

14. Egwaikhide PA, Gimba CE. Analysis of the phytochemical content and antimicrobial activity of plectranthus glanndulosis whole plant. Middle East J Sci Res. 2007;2:135-8.

15. Kangan IA, Michael D, Flthe. Thin-layer Chromatographic (TLC) Separations and Bioassays of Plant Extracts to Identify Antimicrobial Compounds. J Vis Exp. 2014;85:1-8.

16. Zhenyu C, Azhar R, Chaoyue Z, Faya Martin M, Ichiro T, Takaki Y, Rehana I, Mahadev M, Xiaomeng $L$, Jiang $L$. Antiproliferative and apoptotic effects of pinocembrin in human prostate cancer cells. Bangladesh $\mathrm{J}$ Pharmacol. 2013;8:255-62

17. Malarvizhi D, Ajay Kasivishwanathan C, Sridhar M, Gopalakrishnan VK, Hariprasath L. Zaleya decandra exerts anti-cancer activity in HCT-116 cancer cells by impairing mitochondrial activity. Bangladesh J Pharmacol. 2019;14:17480.

18. Banaiee N, Bardarov S, Riska MS, Ponce-De-Leon A, Jacobs AR. Luciferase Reporter Mycobacteriophages for Detection, Identification, and Antibiotic Susceptibility Testing of Mycobacterium tuberculosis in Mexico. J Clin Microbiol. 2001:39:3883-8.

19. Suh SS, Hong JM, Kim EJ, Jung SW, Kim SM, Kim JE, et al. Anti-inflammation and Anti-Cancer Activity of Ethanol Extract of Antarctic Fresh water Microalga. Internat J Med Res. 2018;15:929-36.

20. Baldin VP, Scodro RBL, Lopes-Ortiz MA, de Almeida AL, Gazim ZC, Ferarrese $\mathrm{L}$, et al. Anti-Mycobacterium tuberculosis activity of essential oil and 6,7-dehydroroyleanone isolated from leaves of Tetra deniariparia (Hochst.) Codd (Lamiaceae). Phytomedicine. 2018;47:34-9.

21. Anita sinha HP, Sharma, Binod S, Amit patnaik. Phyto-chemical studies of methanol extracts of Tinospora cordifolia stem by GC-MS. World J Pharm Res. 2017;6:1319-26

22. Ganesh CJ, Vijayashree N, Vidyasagar MS. Evaluation. of the antineoplastic activity of guduchi (Tinospora cordifolia) in cultured HeLa cells. Cancer Lett. 1998;127:71-82.

23. Mark H, Mannino, Ziwen Z, Huaping X, Qian B, Mark R, Wakefield, Yujiang F The paradoxical role of IL-10 in immunity and cancer. Cance Lett. 2015;2:103-7.

24. Mohamed F, Alajmi, Ramzi A, Mothana, Adnan J, Al-Rehaily, et al. Antimycobacterial Activity and Safety Profile Assessment of Alpinia galanga and Tinospora cordifolia. Evid Based Complementary and Altern Med. 2018:27:1-12. 


\section{GRAPHICAL ABSTRACT}

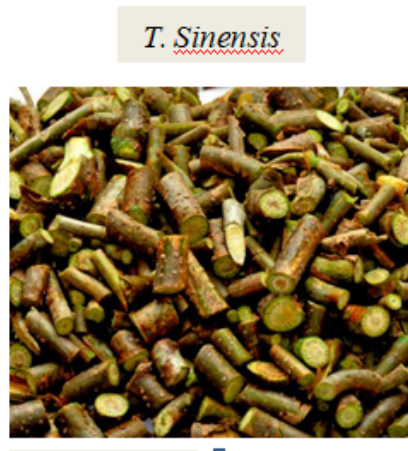

GC-MS

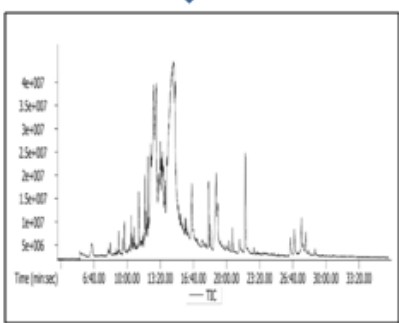

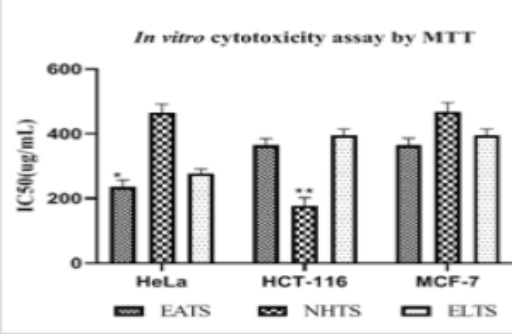

In vitro antitubercular activity by LRP assay

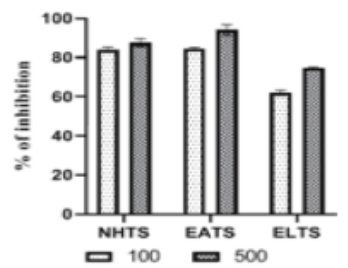

TNF-A

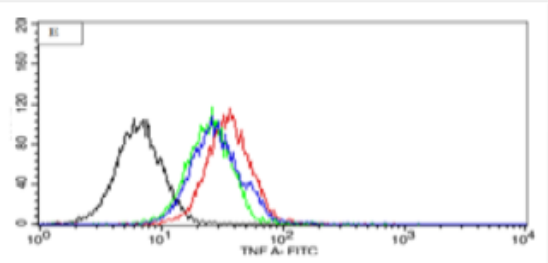

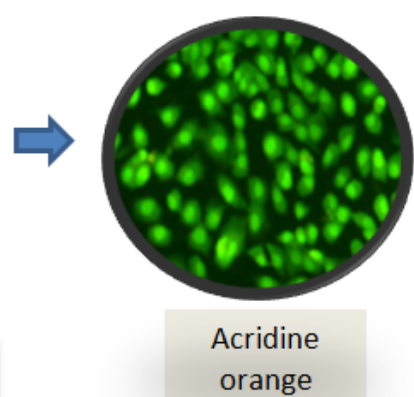

orange

\section{ABOUT AUTHORS}

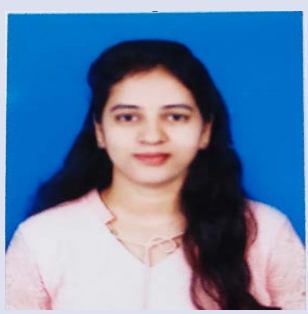

\section{Sreelakshmi Bada Venkatappa Gari}

Research Scholar, Dept. of Pharmaceutical Sciences, Jawaharlal Nehru Technological University Anantapur (JNTUA), Ananthapuramu, Andhra Pradesh, India. Pursuing Full-time Ph.D in JNTUA. Areas of interest- Cell biology, Neuropharmacology, Plant biology

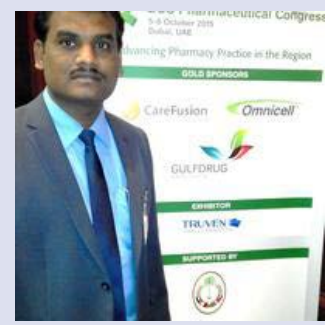

\section{Ramalingam Peraman}

Director (Research) and coordinator (Accreditations) at Raghavendra Institute of Pharmaceutical Education and Research (RIPER) - Autonomous and recognized Research Centre by JNT University Anantapur.

Received 3 research grants from AICTE, DST-SERB, BIRAC-GYTI with worth of 65 lakhs. Areas of interest- Drug Design, Synthesis, characterization, Biological screening, drug stability studies

Cite this article: Gari SBV, Peraman R. Tinospora Sinensis (Lour.) Merr. Stem Modulate The TNF-Alpha Expression In HCT- 116 Tumour Cell, Besides the Inhibitory Effect on Cervical, Colon and Breast Cancer Cell Lines and Mycobacterium Tuberculosis H37Rv. Pharmacog J. 2021;13(1): 8-16. 